\title{
Low T3 Syndrome
}

National Cancer Institute

\section{Source}

National Cancer Institute. Low T3 Syndrome. NCI Thesaurus. Code C130995.

Reduced serum concentration of tri-iodothyronine caused by a variety of non-thyroidal conditions in which there is no dysfunction in the thyroid gland or the hypothalamicpituitary axis. 